\title{
Metabolic activities of eight oil palm progenies grown under aluminum toxicity
}

\author{
EKA TARWACA SUSILA PUTRA ${ }^{1, \bullet}$, BENITO HERU PURWANTO ${ }^{2}$, CAHYO WULANDARI $^{2}$, \\ TAUFAN ALAM ${ }^{1}$ \\ ${ }^{1}$ Department of Agronomy, Faculty of Agriculture, Universitas Gadjah Mada. Jl. Flora No. 1, Bulaksumur, Sleman 55281, Yogyakarta, Indonesia. \\ •email: eka.tarwaca.s@ugm.ac.id \\ ${ }^{2}$ Department of Soil, Faculty of Agriculture, Universitas Gadjah Mada. Jl. Flora No. 1, Bulaksumur, Sleman 55281, Yogyakarta, Indonesia
}

Manuscript received: 10 June 2021. Revision accepted: 10 July 2021.

\begin{abstract}
Putra ETS, Purwanto BH, Wulandari C, Alam T. 2021. Metabolic activities of eight oil palm progenies grown under aluminum toxicity. Biodiversitas 22: 3146-3155. In Indonesia, oil palm is mostly cultivated on red-yellow podzolic soils, which mainly contain the high availability of aluminum (Al). This condition might affect oil palm growth i.e stunted growth and root damage. Therefore, this study was aimed to characterize metabolic activities and growth of eight oil palm progenies under $\mathrm{Al}$ toxicity. The study was conducted from January to December 2018 in Bendosari Hamlet, Madurejo Village, Prambanan Sub-District, Sleman District, Province of Yogyakarta, Indonesia. The trial was laid out in a randomized complete block design (RCBD) factorial with three blocks as replications, with experimental factors including oil palm progenies and $\mathrm{Al}$ concentration. The observation was conducted on $\mathrm{Al}$ concentration in the planting medium, metabolic activities, and oil palm growth. The data were analyzed using ANOVA, PLS-SEM, stepwise regression, hierarchical clustering heatmap, and GGE-Biplot. The results showed that Simalungun, Dumpy, and Yangambi progeny could grow and adapt better than other progenies in $\mathrm{Al}$ toxicity conditions. The resistance to $\mathrm{Al}$ poisoning mechanism was shown by a relatively low activity of $\mathrm{O}_{2}^{-}, \mathrm{H}_{2} \mathrm{O}_{2}$, MDA, and REL, whereas SOD, POD, GB, AARed, $\alpha$-Toch, TPC RDW and, SDW showed higher relatively.
\end{abstract}

Keywords: Aluminium toxicity, oil palm, progeny, red-yellow podzolic

Abbreviations: AARed: Reduced ascorbic acid, GB: Glycine betaine, $\mathrm{H}_{2} \mathrm{O}_{2}$ : Hydrogen peroxide, $\mathrm{O}_{2}$ : Superoxide radical, POD: Peroxide dismutase, Pro: Proline, RDW: Roots dry weight, SDW: Shoots dry weight, REL: Leakage of reactive electrolytes, SOD: Superoxide dismutase, TPC: Total phenolic, MDA: Malondialdehyde, $\alpha$-Toch: Alpha-tocopherol

\section{INTRODUCTION}

Oil palm is the most important plantation commodity in Indonesia. The area currently reaches 16.4 million hectares, of which 13 million hectares are cultivated on mineral soils and only 3.4 million hectares are planted on organic soils. In Indonesia, oil palm is cultivated on the islands of Sumatra, Kalimantan, Sulawesi, and West Papua (Statistics Indonesia 2019). The dominant mineral soils for oil palm cultivation in Indonesia are red-yellow podzolic. The redyellow podzolic characteristics are high acidity level, a predominance of acid reacting cations, and deficiency of alkaline reagent cations. The dominant acid reagent cations are aluminium $(\mathrm{Al})$, iron $(\mathrm{Fe})$, and manganese $(\mathrm{Mn})$ (Alam et al. 2020; Febriani et al. 2017; Irawan and Putra 2019; Khoiriyah et al. 2016; Nurmalasari et al. 2016; Ratnasari et al. 2017; Utami et al. 2019).

Aluminum $(\mathrm{Al})$ is one of the dominant acid reaction cations in red-yellow podzolic. At high acidity levels, the presence of $\mathrm{Al}$ is directly toxic and indirectly triggers a nutritional imbalance. Potential toxicity and nutrient imbalance that occurs due to the high availability of $\mathrm{Al}$ in red-yellow podzolic are the main causes of disruption in the growth and development of oil palm. If the growth of oil palm is disturbed in the long term, it will lead to the low productivity of oil palm plantations in the long run. The low productivity of oil palm occurs for two reasons: the smaller number of fresh fruit bunches (FFB) per stand and the smaller FFB size (Utami et al. 2019; Ratnasari et al. 2017; Khoiriyah et al. 2016).

The impact of high Al availability on red-yellow podzolic directly causes poisoning to oil palms, which begins with stunted growth and root damage. Plant roots become stunted and tend to be short, so that their ability to absorb water and essential mineral nutrients is not optimal (Utami et al. 2019; Ratnasari et al. 2017; Khoiriyah et al. 2016). Al with a high level of availability in red-yellow podzolic causes plant roots to accumulate these ions at high levels. The accumulation of $\mathrm{Al}$ in the roots causes the fixation of carboxylate and phosphate groups on the walls and membranes of the root cells so that the root cells are damaged and lose their permeability. In root cells that are still meristematic, especially in the apical part of the roots, Al toxicity causes membrane leakage and meristem cell death. This fails in mitotic division and enlargement of cell size, so that root elongation is severely inhibited. Therefore, plants that experience $\mathrm{Al}$ poisoning show shorter root organs and irregular curved ends. In large numbers, these irregularly curved root tips provide a visual appearance of the curly root system (Shetty et al. 2021; Utami et al. 2019; Jaiswal et al. 2018; Ratnasari et al. 2017; Khoiriyah et al. 2016).

However, the metabolic mechanism behind the 
inhibition of root development due to $\mathrm{Al}$ poisoning is not completely clear. It is suspected that the event involved an increase in free radical reactivity triggered by $\mathrm{Al}$ poisoning and nutritional imbalances. Several groups of free radicals whose expression is expected to increase with the occurrence of $\mathrm{Al}$ toxicity are superoxide radical $\left(\mathrm{O}_{2}^{-}\right)$, hydroxyl $\left(\mathrm{OH}^{-}\right)$, and hydrogen peroxide $\left(\mathrm{H}_{2} \mathrm{O}_{2}\right)$ (Shetty et al. 2021; Guo et al. 2018; Shahnawaz and Sanadhya 2017). The increased expression of some of these radical compounds causes cell death which begins with membrane damage. Cell membrane damage is caused by membrane lipid peroxidation. Damage to the cell membrane can be indicated by increased malondialdehyde (MDA) and membrane leakage (indicated by leakage of reactive electrolytes). This incident causes the roots not to develop and fail to carry out their function in absorbing water and nutrients. Plants have the potential to lack a supply of water and essential nutrients. Plants that experience this event can also increase free radical activity at the shoots. Increased free radical activity in shoots triggers oxidative damage, which leaves behind damage. Plant leaves experience chlorosis, dry out, and eventually die. This event is especially true for plants that do not have a tolerance to $\mathrm{Al}$ toxicity (Hasanuzzaman et al. 2020; Guo et al. 2018; Shahnawaz and Sanadhya 2017; Khoiriyah et al. 2016; Navascues et al. 2012).

Certain types of plants can tolerate Al toxicity. Plants that are tolerant of Al toxicity can develop mechanisms to counter the negative effects of free radicals. This resistance is in the form of an increase in antioxidant compounds. Antioxidant compounds are quite effective in detoxifying the damaging effects of free radicals. Antioxidant compounds can be divided into two groups, namely enzymatic and non-enzymatic. Some enzymatic antioxidant compounds are superoxide dismutase (SOD), catalase (CAT), ascorbate peroxidase (APX), and peroxide dismutase (POD) (Hasanuzzaman et al. 2020; Guo et al. 2018; Shahnawaz and Sanadhya 2017). In contrast, some nonenzymatic antioxidant compounds are proline (Pro), glycine betaine (GB), reduced ascorbic acid (AARed), alphatocopherol $(\alpha$-Toch), carotenoids, and total phenolic (TPC). Plants that have a high tolerance to free radicals due to $\mathrm{Al}$ poisoning are thought to have the ability to increase the synthesis and activity of several types of antioxidants (Guo et al. 2018; Khoiriyah et al. 2016; Navascues et al. 2012).

Considering that the dominant oil palm commodity occupies red-yellow podzolic, which has the potential for $\mathrm{Al}$ poisoning, innovation is needed in several sectors, namely the development of oil palm seeds and agronomic technology to increase tolerance to $\mathrm{Al}$ poisoning. This study focuses on identifying the relationship between $\mathrm{Al}$ toxicity, nutrient imbalance, and free radicals with antioxidant compounds, root and shoot growth of eight oil palm progenies predominantly cultivated in Indonesia. The eight progenies of oil palms are Yangambi, Avros, Langkat, PPKS 239, Simalungun, PPKS 718, PPKS 540, and Dumpy. Some of them are expected to have a tolerance to $\mathrm{Al}$ toxicity through the emergence of antioxidant compounds to detoxify the damaging effects of free radical compounds.

\section{MATERIALS AND METHODS}

\section{Characteristics of location}

The study was conducted during January-December, 2018 in Bendosari Hamlet, Madurejo Village, Prambanan Sub-District, Sleman District, Province of Yogyakarta, Indonesia. This area was located $\pm 15 \mathrm{~km}$ to the northeast of downtown Yogyakarta City. The altitude of the study site was \pm 37.00 meters above sea level. The total rainfall observed during the experiment was $\pm 727 \mathrm{~mm}$. The average air temperature, relative humidity, and wind velocity were $26.45^{\circ} \mathrm{C}, 78.00 \%$, and $7.00 \mathrm{~m} \mathrm{~s}^{-1}$.

\section{Experimental design}

The trial was laid out in a randomized complete block design (RCBD) factorial with three blocks as replications. The genetic materials used in this study were eight oil palm progenies that were mostly used cultivated in Indonesia sourced from the Indonesian Oil Palm Research Institute (IOPRI) (IOPRI 2013). Eight oil palm progenies consisted of Yangambi, Avros, Langkat, PPKS 239, Simalungun, PPKS 718, PPKS 540, and Dumpy used in the study. The Al concentration tested consisted of two levels, namely normal (without $\mathrm{Al}$ toxicity) and $\mathrm{Al}$ toxicity with concentration of 300 ppm (Utami et al. 2019; Ratnasari et al. 2017; Khoiriyah et al. 2016). Each treatment combination in each block uses five polybags as replications so that the total polybags in each block were 80 units.

\section{Field layout and treatment applications}

Four-month-old oil palm seedlings were chosen as the object of research because their conditions were quite stable and they had begun to accept environmental conditions by the real conditions on the site. Until they were ready for planting, the four-month-old seedlings were in the main nursery stage in the two-stage oil palm nursery model. At the main nursery stage, selected oil palm seedlings were planted in large polybags measuring 40 x 40 $\mathrm{cm}$, without shade and placed on sites with a $90 \times 90 \times 90$ $\mathrm{cm}$ spacing. The research location was in the same condition as the site characteristics for oil palm cultivation, especially in the aspect of the planting medium. The planting medium used was red-yellow podzolic because it was the dominant soil for oil palm cultivation. Maintenance activities include fertilizing, watering, controlling weeds, pests and diseases at the main nursery stage following IOPRI recommendations (IOPRI 2013).

Oil palm was treated with $\mathrm{Al}$ poisoning, and the planting medium was given $\mathrm{Al}$ in aluminum sulfate $\left(\mathrm{Al}_{2}\left(\mathrm{SO}_{4}\right)_{3}\right)$ with a concentration of $300 \mathrm{ppm}$. Giving compound $\mathrm{Al}_{2}\left(\mathrm{SO}_{4}\right)_{3}$ twice during the research period, namely the fifth month (May 2018) and the seventh (July 2018) after planting in the main nursery stage. The volume of $\mathrm{Al}_{2}\left(\mathrm{SO}_{4}\right)_{3}$ was $300 \mathrm{ppm}$ for each polybag with an application time by $500 \mathrm{~mL}$. If the solution was given twice during the study period, each polybag received $1000 \mathrm{~mL}$ of $300 \mathrm{ppm}$ of $\mathrm{Al}_{2}\left(\mathrm{SO}_{4}\right)_{3}$, so the dose of $\mathrm{Al}_{2}\left(\mathrm{SO}_{4}\right)_{3}$ per polybag was $300 \mathrm{mg}$. The dose was chosen because from a preliminary study, $300 \mathrm{mg}$ per polybag $\mathrm{Al}_{2}\left(\mathrm{SO}_{4}\right)_{3}$ had poisoned oil palms in the primary nursery stage. 


\section{Data collection}

\section{Soil sampling and analysis}

Soil analysis was carried out to determine the degree of acidity and $\mathrm{Al}$ concentration in the planting medium. Soil sampling was carried out once in August 2018, exactly a month after giving the second $\mathrm{Al}$ solution, while sampling of plant tissue to determine the $\mathrm{Al}$ concentration in the roots and shoots of oil palm seedlings was carried out in September 2018, exactly two months after giving the second $\mathrm{Al}$ solution. It was expected that the level of $\mathrm{Al}$ uptake by oil palm seedlings was maximum, considering that the sampling period had been two months since the last time the Al solution was given (Sulaeman et al. 2005). Soil analysis was carried out at the General Soil Laboratory, Faculty of Agriculture, Universitas Gadjah Mada, Yogyakarta, Indonesia.

\section{Metabolic activities}

Tissue sampling to determine free radical compounds, antioxidant compounds, roots and shoots dry weight was carried out in December 2018. This timing was selected because oil palm seedlings were eight months old in the main nursery stage or twelve months old in the pre-nursery stage. At that age, oil palm seedlings were generally ready to be transferred to the location. The sample used to measure the activity of free radicals and antioxidants and indicators of cell damage were oil palm seedlings leaves. The leaves selected as samples were the third fully developed leaves counted from the shoots.

The activities of free radical compounds are superoxide radical $\left(\mathrm{SO}_{2}{ }^{-}\right)$(Malecka et al. 2014) and hydrogen peroxide $\left(\mathrm{H}_{2} \mathrm{O}_{2}\right)$ (Bouazizi et al. 2007). Indicators of cell damage due to free radical compound activity were malondialdehyde (MDA) (Gao et al. 2000) and leakage of reactive electrolytes (REL) (Valentovic et al. 2006). Enzymatic antioxidant compounds that were the main indicators of this study were superoxide dismutase (SOD) (Beyer and Fridovich 1987) and peroxide dismutase (POD) (Saravan et al. 2004). Non-enzymatic antioxidant compounds that were also used as indicators of the level of resistance of oil palm plants to $\mathrm{Al}$ toxicity were proline (Pro) (Bates et al. 1973), glycine betaine (GB) (Grieve and Grattan 1983), reduced ascorbic acid (AARed) (Ribeiro et al. 2012), alpha-tocopherol ( $\alpha$-Toch) (Baker et al. 1980), and total phenolic (TPC) (Chun et al. 2003). The dry weight of the oil palm was separated between roots and shoots. A sampling of roots dry weight (RDW) and shoots dry weight (SDW) was carried out simultaneously with sampling for biochemical characterization.

\section{Statistical approach}

Data on Al toxicity in planting media, metabolic activities, and oil palm dry weight must be the normally distributed and homogeneity assumptions before analysis of variance (ANOVA). The data that fulfilled the assumptions were performed using ANOVA ( $p<0.05)$ and continued by LSD-Fisher test $(\mathrm{p}<0.05)$ as a post hoc test (Hinkelman and Kempthorne 2008; Welham et al. 2015). The relationships between metabolic activities with oil palm dry weight were analyzed using partial least square structural equation modelling (PLS-SEM) and stepwise regression analysis (Suryanto et al. 2020). The selection of palm oil progenies under normal and Al toxicity conditions were analyzed using genetic-genetic by environment biplot (GGE-Plot) with average environment coordinate (AEC) method and hierarchical clustering heatmap (Gabriel 1971; Yan et al. 2000; Yan 2001). ANOVA and stepwise regression analysis was carried out using SAS software version 9.4 for Windows with PROC GLM and REG (SAS Institute Inc 2013). PLS-SEM was performed using SmartPLS 3 software (Smith et al. 1993). GGE-Biplot with AEC method was analyzed using Genstat $18^{\text {th }}$ software (Goedhart and Thissen 2016) and hierarchical clustering heatmap performed using R statistical software (v. 3.6.3; R Development Core Team) with the corrplot and entropart package (Marcon and Hérault 2015; Wei 2013).

\section{RESULTS AND DISCUSSION}

\section{Al toxicity in soil medium}

The Al concentration of the planting medium, the degree of acidity of the planting medium, the $\mathrm{Al}$ concentration of the roots and shoots of oil palm seedlings were not influenced by the interaction between progenies and Al toxicity factors (Table 1). Individually, the progenies factor also did not have a significant effect on all of these variables. All of the progeny tested had the same $\mathrm{Al}$ concentration and the degree of acidity of the growing medium and shoot $\mathrm{Al}$ concentration. However, the $\mathrm{Al}$ toxicity factor significantly affected the $\mathrm{Al}$ concentration in the planting medium, the $\mathrm{Al}$ concentration in the roots and shoots of oil palm plants. Only the acidity of the planting medium was not affected by the Al toxicity factor. The media for planting oil palm seedlings that get $\mathrm{Al}$ at the same toxicity level as the planting media for oil palm seedlings that get $\mathrm{Al}$. The Al concentration in the planting medium that received $\mathrm{Al}$ application at a toxic level was significantly higher when compared to the planting medium without Al.

Application of $\mathrm{Al}$ to the growing media under poisoning conditions significantly increased its availability. This showed that the roots of oil palm seedlings more easily absorb Al (Utami et al. 2019; Ratnasari et al. 2017; Khoiriyah et al. 2016). The results showed that oil palm seedlings planted on media with Al toxicity absorbed more Al than media without Al. This was evidenced by the increasing concentration of $\mathrm{Al}$ in the roots and shoots of oil palm seedlings planted on media with high $\mathrm{Al}$ concentrations. Oil palm seedlings planted on planting media without the addition of $\mathrm{Al}$ had lower $\mathrm{Al}$ concentrations in roots and shoots than those treated with Al toxicity (Table 1).

Oil palm seeds planted on planting media without $\mathrm{Al}$ poisoning still absorb $\mathrm{Al}$ at normal levels. This condition causes no metabolic disorders to occur in the oil palm seedlings. Oil palm seeds grown on planting media with $\mathrm{Al}$ toxicity had a very high $\mathrm{Al}$ absorption. Al concentrations in roots and shoots were very high, exceeding normal limits (Table 1). This situation can cause metabolic stress in the tissue, especially in intolerant oil palm progenies, so that in the long term, it can inhibit growth and development and 
low yields of oil palm. Stress metabolic in oil palm progenies can damage the plant for a long time.

All the metabolic variables focused in this study consisted of superoxide radical $\left(\mathrm{O}_{2}^{-}\right)$, hydrogen peroxide $\left(\mathrm{H}_{2} \mathrm{O}_{2}\right)$, superoxide dismutase (SOD), peroxide dismutase (POD), proline (Pro), glycine betaine (GB), reduced ascorbic acid (AARed), alpha-tocopherol ( $\alpha$-Toch), and total phenolic (TPC) were significantly affected by the interaction between oil palm progenies and $\mathrm{Al}$ toxicity (Table 2). Oil palm seedlings that received Al treatment at a toxic level experienced increased free radical activity in the form of $\mathrm{O}_{2}{ }^{-}$and $\mathrm{H}_{2} \mathrm{O}_{2}$, except for Yangambi, Simalungun, and Dumpy progeny. The Avros, Langkat, PPKS 239, PPKS 718, and PPKS 540 progeny significantly increased in $\mathrm{O}_{2}{ }^{-}$and $\mathrm{H}_{2} \mathrm{O}_{2}$ when the planting medium was given $\mathrm{Al}$ at toxic levels. This occurs because giving $\mathrm{Al}$ to the planting medium at a toxic level increased the concentration of $\mathrm{Al}$ in the roots and shoots of Avros, Langkat, PPKS 239, PPKS 718, and PPKS 540 progeny (Table 1). The increase in roots and shoots $\mathrm{Al}$ concentrations might stimulate the synthesis and activity of $\mathrm{O}_{2}^{-}$and $\mathrm{H}_{2} \mathrm{O}_{2}$ (Table 2). In Avros, Langkat, PPKS 239, PPKS 718, and PPKS 540 progeny, the increase in free radical synthesis and activity cannot be stopped because all these progenies cannot develop a defense system in the form of enzymatic or non-enzymatic antioxidant compounds. In Al toxicity conditions, the progeny of the Avros, Langkat, PPKS 239, PPKS 718, and PPKS 540 decreased the synthesis and performance of $\mathrm{O}_{2}^{-}$, $\mathrm{H}_{2} \mathrm{O}_{2}$, AARed, and $\alpha$-Toch. Synthesis of Pro, GB, and TPC in $\mathrm{Al}$ toxicity conditions showed constant values compared to normal conditions in Avros, Langkat, PPKS 239, PPKS 718, and PPKS 540 progeny. Al toxicity conditions caused $\mathrm{O}_{2}{ }^{-}$and $\mathrm{H}_{2} \mathrm{O}_{2}$ to be uncontrolled in the Avros, Langkat, PPKS 239, PPKS 718, and PPKS 540 progeny.

There were differences in $\mathrm{O}_{2}^{-}, \mathrm{H}_{2} \mathrm{O}_{2}$, SOD, POD, Pro, GB, AARed, $\alpha$-Toch, and TPC responses in Yangambi, Simalungun, and Dumpy progeny when compared to Avros, Langkat, PPKS 239, PPKS 718, and PPKS 540 progeny (Table 2). The Yangambi, Simalungun, and Dumpy progeny maintained that $\mathrm{O}_{2}^{-}$and $\mathrm{H}_{2} \mathrm{O}_{2}$ activity did not increase in $\mathrm{Al}$ toxicity conditions. This increased was not followed by an increase in $\mathrm{Al}$ concentration in the roots and shoots of Yangambi, Simalungun, and Dumpy progeny in $\mathrm{O}_{2}$ and $\mathrm{H}_{2} \mathrm{O}_{2}$ activity. This happens because the Yangambi, Simalungun, and Dumpy progeny can develop tolerance mechanisms to increase the synthesis of enzymatic and non-enzymatic antioxidant compounds. The Yangambi and Simalungun progeny developed a type of enzymatic antioxidant compound, while Dumpy progeny was under Al toxicity by SOD and POD. The nonenzymatic antioxidant compounds developed by Yangambi, Simalungun, and Dumpy progeny in Al toxicity were Pro, GB, AARed, $\alpha$-Toch, and TPC (Table 2).

The increase in SOD in Yangambi, Simalungun, and Dumpy progeny during Al poisoning caused degradation of $\mathrm{O}_{2}{ }^{-}$so that its concentration and activity decreased significantly. $\mathrm{O}_{2}$-is converted to $\mathrm{H}_{2} \mathrm{O}_{2}$ by $\mathrm{SOD}$. The Yangambi, Simalungun, and Dumpy progeny can increased POD synthesis and activity under Al toxicity. The high concentration and activity of POD in Yangambi, Simalungun, and Dumpy progeny in $\mathrm{Al}$ poisoning can degrade $\mathrm{H}_{2} \mathrm{O}_{2}$ to water and oxygen. These factors were the main cause of low $\mathrm{O}_{2}{ }^{-}$and $\mathrm{H}_{2} \mathrm{O}_{2}$ in Yangambi, Simalungun, and Dumpy progeny in $\mathrm{Al}$ poisoning.

The Yangambi, Simalungun, and Dumpy progeny can also increase the concentration and activity of several nonenzymatic antioxidants, namely Pro, GB, AARed, $\alpha$-Toch, and TPC in Al stress conditions. Increased Pro, GB, and AARed, $\alpha$-Toch, and TPC neutralized radical electrons from several free radical compounds, including $\mathrm{O}_{2}{ }^{-}$and $\mathrm{H}_{2} \mathrm{O}_{2}$. Electrons derived from $\mathrm{O}_{2}^{-}, \mathrm{H}_{2} \mathrm{O}_{2}$ and other free radical compounds were captured by Pro, GB, AARed, $\alpha$ Toch, and TPC (Shetty et al. 2021; Hasanuzzaman et al. 2020; Guo et al. 2018; Shahnawaz and Sanadhya 2017; Khoiriyah et al. 2016; Navascues et al. 2012). This situation inhibits the rate of lipid peroxidation in the cell membrane so that cells do not leak the membrane and avoid death due to the activity of free radical compounds. The presence of Pro, GB, and AARed, $\alpha$-Toch, and TPC can gradually neutralize the presence of $\mathrm{O}_{2}{ }^{-}$and $\mathrm{H}_{2} \mathrm{O}_{2}$ so that the concentration of both in cells decreases to normal, especially in Yangambi, Simalungun, and Dumpy progeny.

Table 1. The effects of oil palm progenies and $\mathrm{Al}$ toxicity in planting medium

\begin{tabular}{|c|c|c|c|c|}
\hline \multirow[b]{2}{*}{ Treatments } & \multicolumn{4}{|c|}{ Al toxicity in planting medium } \\
\hline & $\begin{array}{c}\text { Al Exchange } \\
(\text { ppm) }\end{array}$ & pH $\mathbf{H}_{2} \mathrm{O}$ & $\begin{array}{l}\text { Al concentration in } \\
\text { roots tissue (ppm) }\end{array}$ & $\begin{array}{l}\text { Al concentration in } \\
\text { shoots tissue (ppm) }\end{array}$ \\
\hline \multicolumn{5}{|l|}{ Progenies } \\
\hline Yangambi & $150.21 \mathrm{a}$ & $5.34 \mathrm{a}$ & $435.28 \mathrm{a}$ & $376.19 a$ \\
\hline Avros & $145.32 \mathrm{a}$ & $5.21 \mathrm{a}$ & $440.22 \mathrm{a}$ & $364.37 \mathrm{a}$ \\
\hline Langkat & $147.54 \mathrm{a}$ & $5.34 \mathrm{a}$ & $430.98 \mathrm{a}$ & $382.00 \mathrm{a}$ \\
\hline PPKS 239 & $149.22 \mathrm{a}$ & $5.43 \mathrm{a}$ & $435.00 \mathrm{a}$ & $367.43 \mathrm{a}$ \\
\hline Simalungun & $148.68 \mathrm{a}$ & $5.41 \mathrm{a}$ & $437.39 \mathrm{a}$ & $368.57 \mathrm{a}$ \\
\hline PPKS 718 & $148.43 \mathrm{a}$ & $5.01 \mathrm{a}$ & $432.17 \mathrm{a}$ & $380.54 \mathrm{a}$ \\
\hline PPKS 540 & $145.79 \mathrm{a}$ & $5.23 \mathrm{a}$ & $438.13 \mathrm{a}$ & $378.42 \mathrm{a}$ \\
\hline Dumpy & $146.31 \mathrm{a}$ & $5.07 \mathrm{a}$ & $433.47 \mathrm{a}$ & $370.62 \mathrm{a}$ \\
\hline \multicolumn{5}{|l|}{ Al toxicity } \\
\hline Normal & $115.23 \mathrm{q}$ & $5.20 \mathrm{a}$ & $125.46 \mathrm{q}$ & $102.37 \mathrm{q}$ \\
\hline Toxic & $645.86 \mathrm{p}$ & $4.85 \mathrm{a}$ & $537.79 \mathrm{p}$ & $458.85 \mathrm{p}$ \\
\hline Interaction & $(-)^{1}$ & $(-)$ & $(-)$ & $(-)$ \\
\hline
\end{tabular}


Table 2 provides information that the concentration of MDA, REL, roots and shoots dry weight of oil palm seedlings were strongly influenced by the interaction between progeny and $\mathrm{Al}$ toxicity. Oil palm seedlings that received Al toxicity treatment experienced an increase in several indicators of cell damage, namely MDA and REL, except for Yangambi, Simalungun, and Dumpy progeny. Avros, Langkat, PPKS 239, PPKS 718, and PPKS 540 progeny experienced an increase in cell damage due to $\mathrm{Al}$ toxicity as indicated by increased levels of MDA and REL. Avros, Langkat, PPKS 239, PPKS 718, and PPKS 540 progeny had significantly higher levels of MDA and REL under Al toxicity when compared to normal conditions.

The MDA indicator positively correlates with the level of membrane damage due to lipid peroxidation caused by $\mathrm{O}_{2}{ }^{-}$and $\mathrm{H}_{2} \mathrm{O}_{2}$. If cells have high levels of MDA, it means that the cell membrane has been damaged. Membrane damage also occurs due to membrane leakage, triggered by free radical activity, especially in ROS and the REL level indicates the leakage rate. The REL indicator measures the membrane leakage rate based on the electrolyte solution that leaves the cell and is then captured by the electrodes (Shetty et al. 2021; Shahnawaz and Sanadhya 2017; Khoiriyah et al. 2016; Navascues et al. 2012). Avros, Langkat, PPKS 239, PPKS 718, and PPKS 540 progeny had high levels of MDA and REL when suppressed by $\mathrm{Al}$ due to increased $\mathrm{O}_{2}{ }^{-}$and $\mathrm{H}_{2} \mathrm{O}_{2}$ activity in cells. In Avros, Langkat, PPKS 239, PPKS 718, and PPKS 540 progeny, if the $\mathrm{Al}$ uptake is high, ROS activity cannot be avoided because there is no defense mechanism development the form of enzymatic or non-enzymatic antioxidants. Therefore, Avros, Langkat, PPKS 239, PPKS 718, and PPKS 540 progeny had higher cell damage levels than Yangambi, Simalungun, and Dumpy progeny, which experienced Al stress based on MDA and REL indicators.

The Yangambi, Simalungun, and Dumpy progeny were proven to prevent cell damage when planted in Al stress conditions because the levels of MDA and REL were relatively the same compared to plants grown in normal conditions. Cell membrane damage can be prevented in these three progeny because with Al stress, ROS reactivity can be neutralized using enzymatic or non-enzymatic antioxidant compounds (Shetty et al. 2021; Hasanuzzaman et al. 2020; Guo et al. 2018; Shahnawaz and Sanadhya 2017). In Yangambi, Simalungun, and Dumpy progeny in Al stress, all of these progeny can improve the performance of SOD, POD, Pro, GB, AARed, $\alpha$-Toch, and TPC so that damage to cell membranes from ROS compounds can be controlled. Therefore, the cell membranes in the Yangambi, Simalungun, and Dumpy progeny remained healthy, which was indicated by low levels of MDA and REL even though oil palm seedlings were exposed to Al stress.

Avros, Langkat, PPKS 239, PPKS 718, and PPKS 540 progeny experienced a metabolic crisis when exposed to $\mathrm{Al}$ poisoning as indicated by increased activity of ROS compounds, no development of enzymatic or nonenzymatic antioxidant performance, and cell membrane damage. This condition causes the cells not to divide and expand, so the organs do not grow and develop. The failure of organ growth causes oil palm seedlings to have shorter, smaller, lighter roots and canopies. This condition causes the Avros, Langkat, PPKS 239, PPKS 718, and PPKS 540 progeny to have a dry weight of roots and shoots in $\mathrm{Al}$ poisoning than oil palm seedlings grown in normal conditions.

Different things were found in the Yangambi, Simalungun, and Dumpy progeny. The three progeny did not experience a metabolic crisis due to Al toxicity as indicated by the weak activity of ROS compounds, maximum performance of enzymatic and non-enzymatic antioxidants, and low levels of cell membrane damage. The Yangambi, Simalungun, and Dumpy progeny cells remained healthy even though the oil palm seeds grew under Al toxicity. The three progeny have succeeded in developing internal defence mechanisms to protect themselves from free radical attacks using antioxidant compounds. The indicator that the cells in the Yangambi, Simalungun, and Dumpy progeny remained healthy, namely the low levels of MDA and REL in oil palm seedlings that grew in Al stress. Healthy cells can carry out the mitotic division and enlargement activities perfectly so that the Yangambi, Simalungun, and Dumpy progeny have longer, larger, and heavier root and canopy sizes even in a state of Al toxicity. In the three progeny, root and canopy size were almost the same when growing in Al stress and normal environment.

\section{Relationship between metabolic activities and oil palm dry weight}

A general assessment of the relationship between metabolic activities with oil palm dry weight can be carried out using partial least square structural equation modelling (PLS-SEM) and stepwise regression analysis. The PLSSEM results were used for the initial screening of parameters derived from enzymatic antioxidant compounds, non-enzymatic compounds, free radical compound activity, and indicators of cell damage due to the free radical compound activity, which showed significant differences (Figure 1). PLS-SEM results showed that enzymatic antioxidant compounds, non-enzymatic compounds, free radical compound activity, and indicators of cell damage due to the free radical compound activity showed a very significant difference to dry weight $(\mathrm{p}<0.01)$ (Figure 1). The results of screening using PLS-SEM was used as a guide for stepwise regression analysis. The results of the stepwise regression showed that hydrogen peroxide $\left(\mathrm{H}_{2} \mathrm{O}_{2}\right)$ had a very significant effect $(\mathrm{p}<0.01)$ on the dry weight of palm oil, while glycine betaine (GB) and malondialdehyde (MDA) had a significant effect ( $p<0.05$ ). Increasing the $\mathrm{H}_{2} \mathrm{O}_{2}, \mathrm{~GB}$, and MDA values generally reduced the dry weight of palm oil. The stepwise regression equation was $\mathrm{Y}=153.61 * *_{-} 0.53 \mathrm{H}_{2} \mathrm{O}_{2} *_{*}-0.009 \mathrm{~GB} *_{-}-13.61$ $\mathrm{MDA}^{*}\left(\mathrm{R}^{2}=0.990 * *\right)$. 
Table 2. The interaction between oil palm progenies and $\mathrm{Al}$ toxicity in metabolic activities and dry weight

\begin{tabular}{|c|c|c|c|c|c|c|c|c|c|c|c|c|c|c|}
\hline \multirow{2}{*}{\multicolumn{2}{|c|}{ Treatments }} & \multicolumn{13}{|c|}{ Metabolic Activities and Dry Weight of Oil Palm Progenies } \\
\hline & & $\begin{array}{c}\mathbf{O}_{2}^{-} \\
\left(\mu \mathrm{mol} \mathrm{g^{-1 }}\right)\end{array}$ & $\begin{array}{c}\mathrm{H}_{2} \mathrm{O}_{2} \\
(\mathbf{p p m})\end{array}$ & $\begin{array}{c}\text { SOD } \\
\text { (unit } \mathbf{~ m L}^{-1} \text { ) }\end{array}$ & $\begin{array}{c}\text { POD } \\
(\text { unit mg protein-1) }\end{array}$ & $\begin{array}{c}\text { Pro } \\
\left.(\mu \mathrm{mol} \mathrm{g})^{-1}\right)\end{array}$ & $\begin{array}{c}\text { GB } \\
(\mathbf{p p m})\end{array}$ & $\begin{array}{l}\text { AARed } \\
\left(\mathrm{mg} \mathrm{g}^{-1}\right)\end{array}$ & $\begin{array}{l}\alpha-\text {-Toch } \\
\left(\mathrm{mg} \mathrm{g}^{-1}\right)\end{array}$ & $\begin{array}{c}\text { TPC } \\
\left(\mathbf{m g ~ g}^{-1}\right)\end{array}$ & 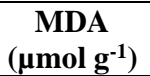 & $\begin{array}{l}\text { REL } \\
(\%)\end{array}$ & $\begin{array}{c}\text { RDW } \\
(\mathrm{g})\end{array}$ & $\begin{array}{c}\text { SDW } \\
(\mathrm{g})\end{array}$ \\
\hline \multirow[t]{8}{*}{ Normal } & Yangambi & $0.35 \mathrm{~b}$ & $11.00 \mathrm{~b}$ & $1.50 \mathrm{~b}$ & $0.15 \mathrm{~b}$ & $25.38 \mathrm{~b}$ & $300.00 \mathrm{~b}$ & $2.50 \mathrm{~b}$ & $1.02 \mathrm{~b}$ & $3.08 \mathrm{~b}$ & $0.50 \mathrm{~b}$ & $10.00 \mathrm{~b}$ & $55.30 \mathrm{a}$ & $130.22 \mathrm{a}$ \\
\hline & Avros & $0.30 \mathrm{~b}$ & $15.26 \mathrm{~b}$ & $1.55 \mathrm{~b}$ & $0.10 \mathrm{~b}$ & $20.95 \mathrm{~b}$ & 290.45 b & $2.45 \mathrm{~b}$ & $1.45 \mathrm{~b}$ & $2.58 \mathrm{~b}$ & $0.45 \mathrm{~b}$ & $12.38 \mathrm{~b}$ & $45.88 \mathrm{a}$ & $135.45 \mathrm{a}$ \\
\hline & Langkat & $0.29 \mathrm{~b}$ & $13.47 \mathrm{~b}$ & $1.46 \mathrm{~b}$ & $0.14 \mathrm{~b}$ & $24.26 \mathrm{~b}$ & $305.96 \mathrm{~b}$ & $2.38 \mathrm{~b}$ & $1.08 \mathrm{~b}$ & $3.24 \mathrm{~b}$ & $0.60 \mathrm{~b}$ & $11.42 \mathrm{~b}$ & $60.84 \mathrm{a}$ & $140.86 \mathrm{a}$ \\
\hline & PPKS 239 & $0.40 \mathrm{~b}$ & $12.98 \mathrm{~b}$ & $1.38 \mathrm{~b}$ & $0.11 \mathrm{~b}$ & $25.26 \mathrm{~b}$ & $300.80 \mathrm{~b}$ & $2.80 \mathrm{~b}$ & $1.42 \mathrm{~b}$ & $3.06 \mathrm{~b}$ & $0.39 \mathrm{~b}$ & $10.87 \mathrm{~b}$ & $58.65 \mathrm{a}$ & $138.85 \mathrm{a}$ \\
\hline & Simalungun & $0.32 \mathrm{~b}$ & $16.65 \mathrm{~b}$ & $1.43 \mathrm{~b}$ & $0.15 \mathrm{~b}$ & $22.84 \mathrm{~b}$ & $295.88 \mathrm{~b}$ & $2.55 \mathrm{~b}$ & $1.30 \mathrm{~b}$ & $3.50 \mathrm{~b}$ & $0.55 \mathrm{~b}$ & $12.22 \mathrm{~b}$ & $55.45 \mathrm{a}$ & $135.20 \mathrm{a}$ \\
\hline & PPKS 718 & $0.39 \mathrm{~b}$ & $11.24 \mathrm{~b}$ & $1.27 \mathrm{~b}$ & $0.12 \mathrm{~b}$ & $23.87 \mathrm{~b}$ & $310.48 \mathrm{~b}$ & $2.45 \mathrm{~b}$ & $1.20 \mathrm{~b}$ & $2.98 \mathrm{~b}$ & $0.54 \mathrm{~b}$ & $11.55 \mathrm{~b}$ & $53.24 \mathrm{a}$ & $136.21 \mathrm{a}$ \\
\hline & PPKS 540 & $0.34 \mathrm{~b}$ & $15.26 \mathrm{~b}$ & $1.29 \mathrm{~b}$ & $0.12 \mathrm{~b}$ & $24.45 \mathrm{~b}$ & $310.98 \mathrm{~b}$ & $2.65 \mathrm{~b}$ & $1.32 \mathrm{~b}$ & $3.36 \mathrm{~b}$ & $0.59 \mathrm{~b}$ & $10.33 \mathrm{~b}$ & $54.28 \mathrm{a}$ & $134.43 \mathrm{a}$ \\
\hline & Dumpy & $0.38 \mathrm{~b}$ & $13.21 \mathrm{~b}$ & $1.39 \mathrm{~b}$ & $0.14 \mathrm{~b}$ & $25.08 \mathrm{~b}$ & $300.58 \mathrm{~b}$ & $2.24 \mathrm{~b}$ & $1.40 \mathrm{~b}$ & $3.00 \mathrm{~b}$ & $0.47 \mathrm{~b}$ & $13.24 \mathrm{~b}$ & $55.32 \mathrm{a}$ & $132.48 \mathrm{a}$ \\
\hline \multirow[t]{8}{*}{ Toxic } & Yangambi & $0.40 \mathrm{~b}$ & $13.02 \mathrm{~b}$ & $5.00 \mathrm{a}$ & $0.55 \mathrm{a}$ & $115.08 \mathrm{a}$ & $954.32 \mathrm{a}$ & $6.58 \mathrm{a}$ & $2.90 \mathrm{a}$ & $9.86 \mathrm{a}$ & $0.65 \mathrm{~b}$ & $10.48 \mathrm{~b}$ & $50.44 \mathrm{a}$ & $128.54 \mathrm{a}$ \\
\hline & Avros & $1.25 \mathrm{a}$ & $78.13 \mathrm{a}$ & $0.35 \mathrm{c}$ & $0.02 \mathrm{c}$ & $25.34 \mathrm{~b}$ & $320.32 \mathrm{~b}$ & $0.55 \mathrm{c}$ & $0.25 \mathrm{c}$ & $3.25 \mathrm{~b}$ & $2.00 \mathrm{a}$ & $25.44 \mathrm{a}$ & $20.55 \mathrm{~b}$ & $80.75 \mathrm{~b}$ \\
\hline & Langkat & $1.09 \mathrm{a}$ & $80.54 \mathrm{a}$ & $0.34 \mathrm{c}$ & $0.03 \mathrm{c}$ & $30.54 \mathrm{~b}$ & $315.65 \mathrm{~b}$ & $0.45 \mathrm{c}$ & $0.34 \mathrm{c}$ & $3.54 \mathrm{~b}$ & $2.38 \mathrm{a}$ & $30.98 \mathrm{a}$ & $20.45 \mathrm{~b}$ & $75.54 \mathrm{~b}$ \\
\hline & PPKS 239 & $1.36 \mathrm{a}$ & $77.21 \mathrm{a}$ & $0.50 \mathrm{c}$ & $0.02 \mathrm{c}$ & $28.34 \mathrm{~b}$ & $318.21 \mathrm{~b}$ & $0.64 \mathrm{c}$ & $0.20 \mathrm{c}$ & $3.24 \mathrm{~b}$ & $1.85 \mathrm{a}$ & $28.65 \mathrm{a}$ & $25.68 \mathrm{~b}$ & $85.42 \mathrm{~b}$ \\
\hline & Simalungun & $0.38 \mathrm{~b}$ & $20.14 b$ & $4.95 \mathrm{a}$ & $0.45 \mathrm{a}$ & $110.14 \mathrm{a}$ & $895.32 \mathrm{a}$ & $5.58 \mathrm{a}$ & $2.50 \mathrm{a}$ & $10.08 \mathrm{a}$ & $0.55 \mathrm{~b}$ & $12.58 \mathrm{~b}$ & $52.44 \mathrm{a}$ & $130.40 \mathrm{a}$ \\
\hline & PPKS 718 & $1.50 \mathrm{a}$ & $78.22 \mathrm{a}$ & $0.27 \mathrm{c}$ & $0.04 \mathrm{c}$ & $30.58 \mathrm{~b}$ & $315.32 \mathrm{~b}$ & $0.65 \mathrm{c}$ & $0.30 \mathrm{c}$ & $3.21 \mathrm{~b}$ & $1.95 \mathrm{a}$ & $26.54 \mathrm{a}$ & $24.37 \mathrm{~b}$ & $83.44 \mathrm{~b}$ \\
\hline & PPKS 540 & $1.25 \mathrm{a}$ & $69.75 \mathrm{a}$ & $0.47 \mathrm{c}$ & $0.05 \mathrm{c}$ & $27.98 \mathrm{~b}$ & $310.54 \mathrm{~b}$ & $0.38 \mathrm{c}$ & $0.28 \mathrm{c}$ & $3.30 \mathrm{~b}$ & $2.22 \mathrm{a}$ & $25.88 \mathrm{a}$ & $24.22 \mathrm{~b}$ & $85.44 \mathrm{~b}$ \\
\hline & Dumpy & $0.42 \mathrm{~b}$ & $16.57 \mathrm{~b}$ & $4.37 \mathrm{a}$ & $0.50 \mathrm{a}$ & $105.65 \mathrm{a}$ & $850.48 \mathrm{a}$ & $6.08 \mathrm{a}$ & $2.85 \mathrm{a}$ & $8.94 \mathrm{a}$ & $0.55 \mathrm{~b}$ & $13.54 \mathrm{~b}$ & $53.52 \mathrm{a}$ & $130.85 \mathrm{a}$ \\
\hline \multicolumn{2}{|c|}{ Interaction } & + & + & + & + & + & + & + & + & + & + & + & + & + \\
\hline
\end{tabular}

Note: Numbers followed by the same letters in the same row were not significantly different by LSD-Fisher test $(\mathrm{p}<0.05) .(*)$ indicates had interaction between treatment factors. Superoxide radical: $\mathrm{O}_{2}^{-}$, Hydrogen peroxide: $\mathrm{H}_{2} \mathrm{O}_{2}$, Superoxide dismutase: SOD, Peroxide dismutase: POD, Proline: Pro, Glycine betaine: GB, Reduced ascorbic acid: AARed, Alpha-tocopherol: $\alpha$-Toch,

Total phenolic: TPC, Malondialdehyde: MDA, Leakage of reactive electrolytes: REL, Roots dry weight: RDW, Shoots dry weight: SDW. 


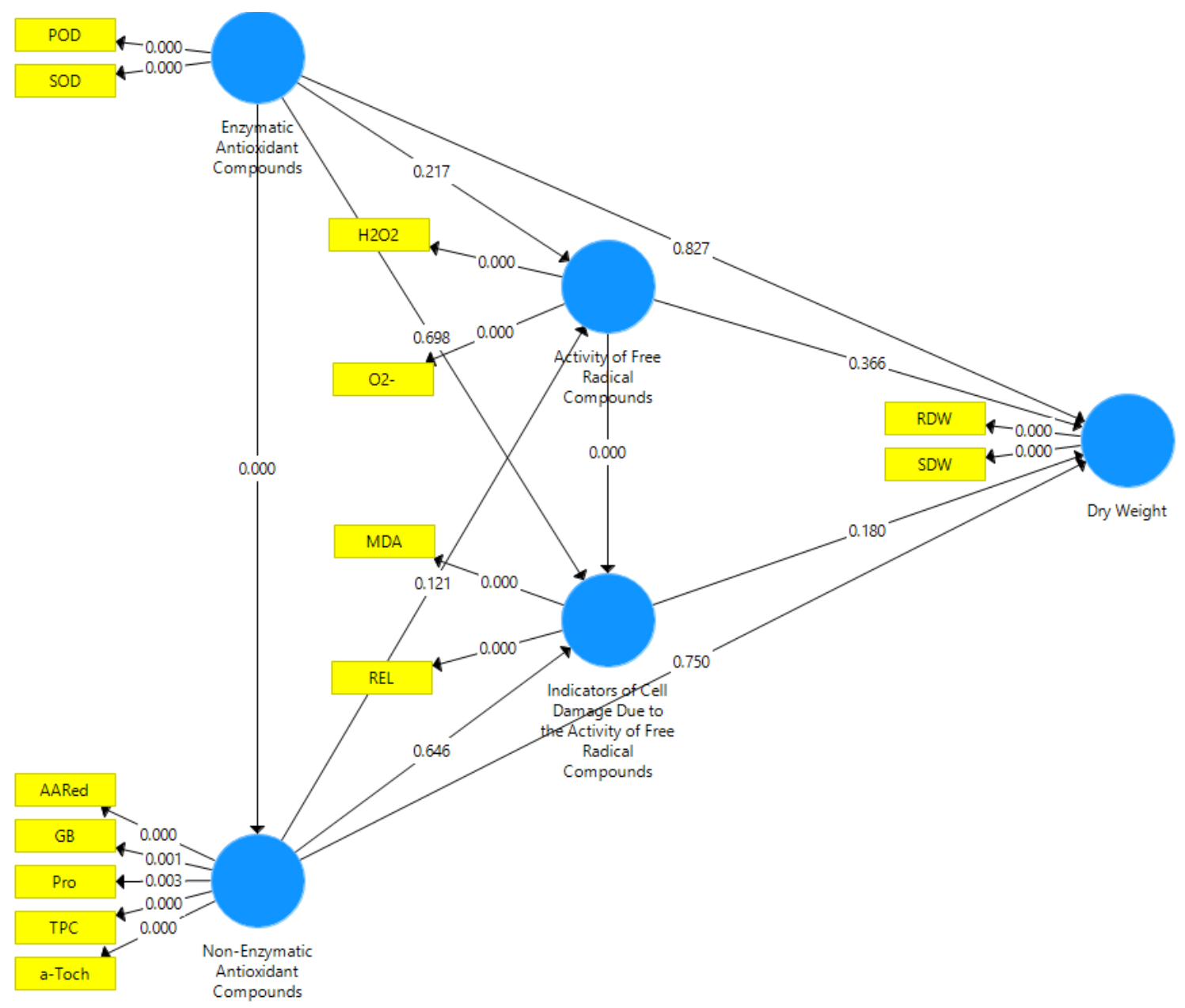

Figure 1. Relationship between metabolic activities and oil palm dry weight using partial least square structural equation modelling (PLS-SEM) and stepwise regression analysis. PLS-SEM was used as a guide for stepwise regression analysis with the regression equation was $\mathrm{Y}=153.61 * *_{-}-0.53 \mathrm{H}_{2} \mathrm{O}_{2} * *_{-} 0.009 \mathrm{~GB} *-13.61 \mathrm{MDA} *\left(\mathrm{R}^{2}=0.990 * *\right)$, and showing a very significant effect when $\mathrm{p}<0.01$ and a significant effect with $\mathrm{p}<0.05$

\section{Selection of palm oil progenies under normal and Al toxicity conditions}

Assessment of stability and adaptability mechanism of oil palm progenies under normal and $\mathrm{Al}$ toxicity conditions using genetic-genetic by environment biplot (GGE-Biplot) and hierarchical clustering heatmap. Oil palm dry weight and progenies stability can be evaluated by GGE-biplot using the average environment coordinate (AEC) method (Yan 2001). One arrow passing the midpoint of the environment is the AEC abscissa depicting the mean dry weight under normal and $\mathrm{Al}$ toxicity conditions. The direction of the AEC abscissa arrow is drawn past the origin point of the biplot and the environmental mean circle. Meanwhile, the perpendicular line from the abscissa of the AEC is the ordinate of the AEC (Kaya et al. 2006). Absis AEC following the direction of the arrow indicates the greater the main effect of progenies (Yan 2001). The presence of two arrows indicates the AEC ordinate. Yan and Rajcan (2002) stated that the ideal genotype is a genotype that has a large $\mathrm{PC}_{1}$ score (high mean yield) and a small $\mathrm{PC}_{2}$ absolute score (high stability).
The Langkat, PPKS 239, PPKS 718, and Avros progeny could be planted and adapted under normal conditions (without Al toxicity) since they were likely susceptible under Al toxicity treatment (Figure 2). Based on the assessment of the level of stability, it showed that Langkat and PPKS 239 progeny had a relatively high level of stability, while PPKS 718 progeny had a relatively low level of stability. The length of line indicates the level of stability for each progeny. The lower line indicates the higher the level of stability and vice versa. The Al toxicity condition showed that Simalungun, Dumpy, and Yangambi progeny could growth and adaptability was better than other progenies. Dumpy showed a relatively high level of stability, while Simalungun and Yangambi progeny had relatively low stability.

\section{Hierarchical clustering heatmap of oil palm progenies in Al toxicity condition}

This was reinforced by the heatmap hierarchical clustering results, which showed that Dumpy, Simalungun, and Yangambi progeny in $\mathrm{Al}$ toxicity conditions had 
relatively lower $\mathrm{O}_{2}^{-}, \mathrm{H}_{2} \mathrm{O}_{2}$, MDA, and REL activity, while SOD, POD, GB, AARed, $\alpha$-Toch, TPC, RDW and, SDW were relatively higher (Figure 3 ). This is because each plant genetic has different adaptability to environmental factors (Klee and Tieman 2013). Giller et al. (2011) suggest that each plant genetics has a different response in absorbing nutrients, fertilizing, and applying lime under different environmental conditions.

In the case of biotic and abiotic stress, an imbalance in cellular homeostasis and an increase in the accumulation of ROS in plant tissue (Gratao et al. 2005). In Al poisoning, Al first accumulates in all oil palm progeny roots, which then spreads to other plant parts. Al toxicity occurs in the plasma membrane. There will be phospholipid binding by $\mathrm{Al}$ on the plasma membrane, changes in the composition of fatty acids on the plasma membrane, decreases fluidity and increases permeability. In addition, Al can cause oxidative stress, resulting in the production and accumulation of ROS, leading to membrane lipid peroxidation (Ma et al. 2012; Ribero et al. 2012; Sharma and Dubey 2007).

Although the level of Al toxicity was the same in all progenies, the level of damage to sensitive progenies would be much heavier than insensitive progenies. Oxidative stress caused by $\mathrm{Al}$ ions causes $\mathrm{Al}$ poisoning. This was because the level of plant tolerance to $\mathrm{Al}$ related to the plant antioxidant system activity and involves enzymatic and non-enzymatic antioxidant mechanisms to eliminate ROS generated during oxidative stress. This is since higher Al concentrations in the roots lead to lower lipid peroxidation. The involvement of antioxidant enzymes is very important to eliminate ROS. The removal of $\mathrm{O}_{2}{ }^{-}$and $\mathrm{H}_{2} \mathrm{O}_{2}$ is very important to maintain the balance of cellular homeostasis because the reaction of $\mathrm{O}_{2}{ }^{-}$and $\mathrm{H}_{2} \mathrm{O}_{2}$ can result in hydroxyl radicals $(\mathrm{OH})$ through the Haber-Weiss reaction (Edreva 2005). SOD was the first enzyme to combat ROS, converting $\mathrm{O}_{2}^{-}$to $\mathrm{H}_{2} \mathrm{O}_{2}$ (Gratao et al. 2005; Sharma and Dubey 2007).

On the other hand, the CAT, POX, APX, and GPX enzymes complement the ROS elimination process by converting $\mathrm{H}_{2} \mathrm{O}_{2}$ to water and oxygen (Gratao et al. 2005). The non-enzymatic that participate in the defence system against Al poisoning were AARed, GSH, $\alpha$-Toch, and carotenoids (Gratao et al. 2005). AARed and GSH are very potent antioxidants that can react directly with ROS and serve as electron donors for key enzymes of enzymatic antioxidant systems such as APX and GPX (Noctor et al. 2012).

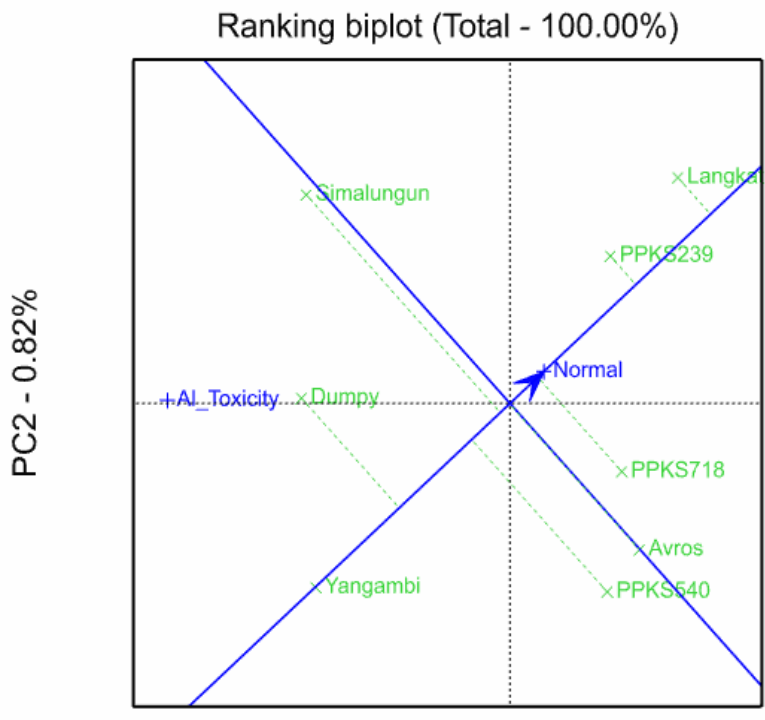

PC1 - $99.18 \%$

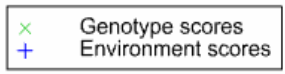

Normal

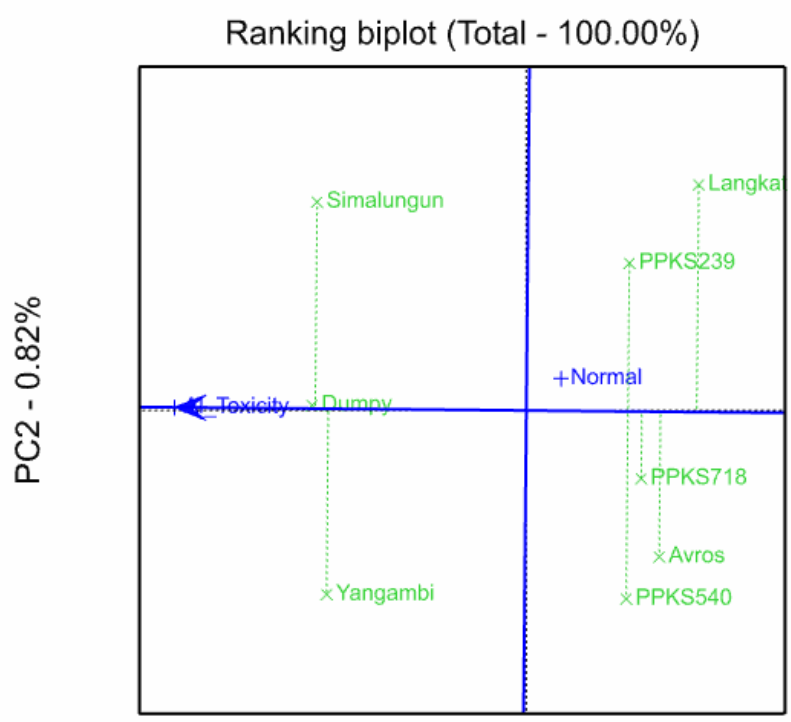

PC1 - $99.18 \%$

Genotype scores

Environment scores

Figure 2. GGE-Biplot with AEC method based on environment focused scaling of the mean values and stability of oil palm progenies in normal and $\mathrm{Al}$ toxicity conditions 


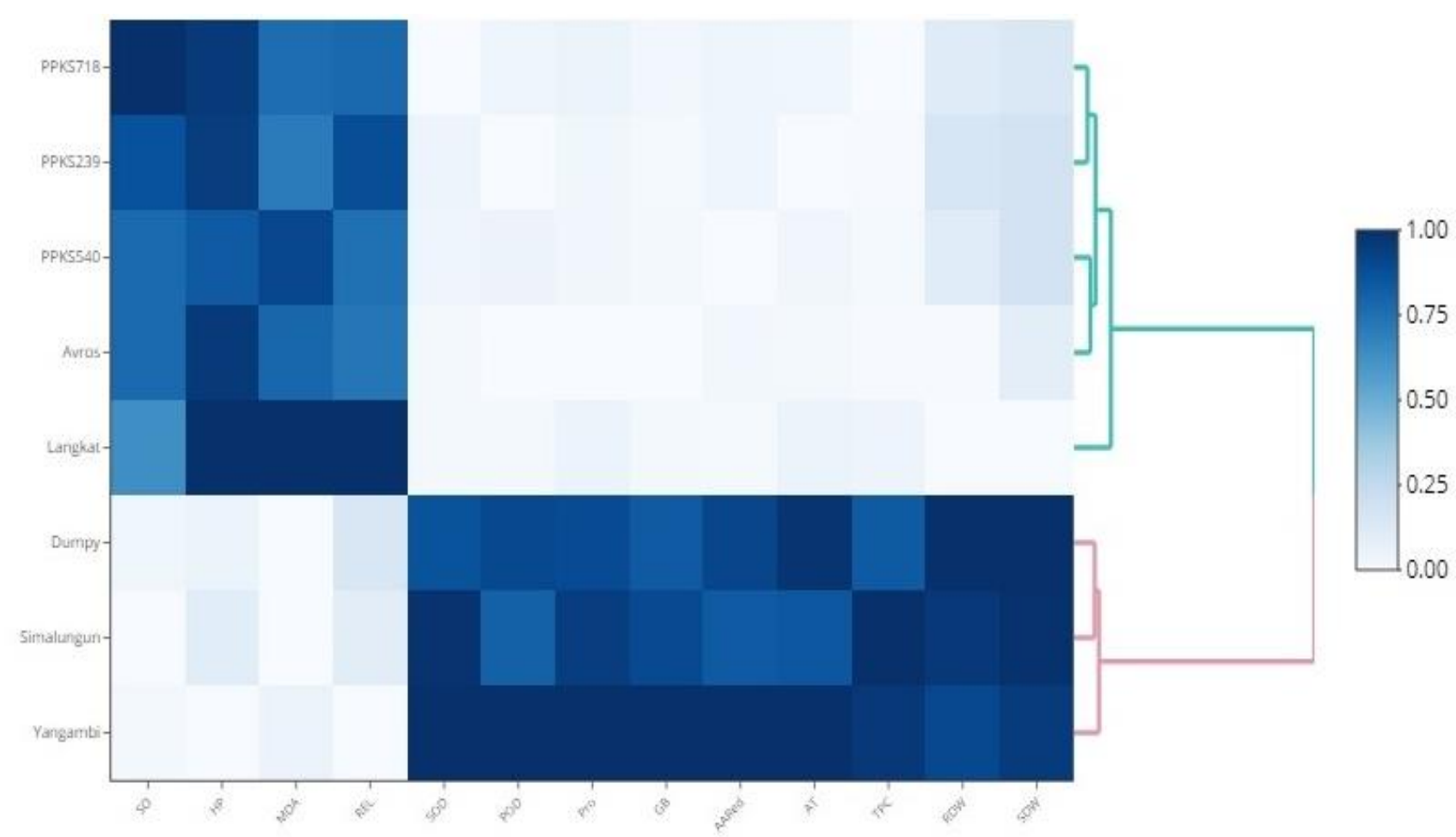

Figure 3. Hierarchical clustering heatmap of oil palm progenies in Al toxicity condition. $R$ coefficient a value of $0-1$ indicates a very weak-very strong $r$ value.

\section{ACKNOWLEDGEMENTS}

The research for this article was fully funded by Universitas Gadjah Mada through the university grant-inaid scheme under PTUPT (2018-2019).

\section{REFERENCES}

Alam S, Purwanto BH, Hanudin E, Putra ETS. 2020. Soil diversity influences on oil palm productivity in ultramafic ecosystems, Southeast Sulawesi, Indonesia. Biodiversitas 21 (11): 5521-5530. DOI: $10.13057 /$ biodiv/d211161.

Baker H, Frank O, De-Angelis B, Feingold S. 1980. Plasma tocopherol in man at various times after ingesting free or acetylated tocopherol. Nutr Rep Intl 21: 531-536.

Bates LS, Waldren RP, Teare ID. 1973. Rapid determination of free proline for water stress studies. Plant Soil 39: 205-207. DOI: 10.1007/BF00018060.

Beyer WF, Fridovich I. 1987. Assaying for superoxide dismutase activity; some large consequences of minor changes of conditions. Anal Biochem 161: 559-566. DOI: 10.1016/0003-2697(87)90489-1.

Bouazizi H, Jouili H, Ferjani EE. 2007. Effects of copper excess on growth, $\mathrm{H}_{2} \mathrm{O}_{2}$ production, and peroxidase activities in maize seedlings (Zea mays L.). Pak J Biol Sci 10 (5): 751-756. DOI: 10.3923/pjbs.2007.751.756.

Chun OY, Kim DO, Lee CY. 2003. Superoxide radical scavenging activity of the major polyphenols in fresh plums. J Agric Food Chem 51: 8067-8072. DOI: 10.1021/jf034740d.

Edreva A. 2005. Generation and scavenging of reactive oxygen species in chloroplasts; a submolecular approach. Agr Ecosyst Environ 30: 119133. DOI: 10.1016/j.agee.2004.10.022.

Febriani DNS, Putra ETS, Tohari. 2017. Root morphological responses of oil palm (Elaeis guineensis Jacq.) hybrids to copper toxicity. Agric Sci 2 (2): 79-84. DOI: 10.22146/ipas.25903.
Gabriel KR. 1971. The biplot graphic display of matrices with application to principal component analysis. Biomet 58: 453467. DOI: $10.2307 / 2334381$.

Gao X, Ohlander M, Jeppsson N, Bjork L, Trajkovski V. 2000. Changes in antioxidant effects and their relationship to phytonutrients in fruits of sea buckthorn (Hippophae rhamnoides L.) during maturation. J Agric Food Chem 48 (5): 1485-1490. DOI: 10.1021/jf991072g.

Giller KE, Tittonell P, Rufino MC, van Wijk MT, Zingore S, Mapfumo P, Adjeinsiah S, Herrero M, Chikowo R, Corbeels M, Rowe EC, Baijukya F, Mwijage A, Smith J, Yeboah E, van der Burg WJ, Sanogo OM, Misiko M, de Ridder N, Karanja S, Kaizzi C, K’ungu J, Mwale M, Nwaga D, Pacini C, Vanlauwe B. 2011. Communicating complexity; Integrated assessment of trade-offs concerning soil fertility management within African farming system to support innovation and development. Agric Syst 104 (2): 191-203. DOI: 10.1016/j.agsy.2010.07.002.

Goedhart PW, Thissen JTNM. 2016. Biometrics GenStat Procedure Library Manual. $18^{\text {th }}$ ed. Wageningen University and Research Center, NL.

Gratao PL, Polle A, Lea PJ, Azevedo RA. 2005. Making the life of heavy metal-stressed plants a little easier. Funct Plant Biol 32: 481-494. DOI: 10.1071/FP05016.

Grieve CM, Grattan SR. 1983. Rapid assay for determination of water soluble quarternary ammonium compounds. Plant Soil 70: 303-307. DOI: $10.1007 / \mathrm{BF} 02374789$.

Guo P, Qi YP, Cai YT, Yang TY, Yang LT, Huang ZR, Chen LS. 2018. Aluminum effects on photosynthesis, reactive oxygen species and methylglyoxal detoxification in two citrus species differing in aluminum tolerance. Tree Physiol 38: 1548-1565. DOI: 10.1093/treephys/tpy035.

Hasanuzzaman M, Bhuyan MHMB, Zulfiqar F, Raza A, Mohsin SM, Mahmud J, Fujita M, Fotopoulos V. 2020. Reactive oxygen species and antioxidant defense in plants under abiotic stress; revisiting the crucial role of a universal defense regulator. Antioxidants 9: 152.DOI: 10.3390/antiox9080681.

Hinkelman K, Kempthorne O. 2008. Design and Analysis of Experiments. $2^{\text {nd }}$ ed. John Wiley and Sons, USA.

IOPRI. 2013. Technical Guidance for Oil Palms Nursery. Indonesia Oil Palm Research Institute. 
Irawan W, Putra ETS. 2020. The effect of potassium addition on oil palm (Elaeis guineensis Jacq.) root anatomic properties under drought stress. Caraka Tani: J Sustain Agric 35 (1): 54-65. DOI: 10.20961/carakatani.v35i1.32578.

Jaiswal SK, Naamala J, Dakora FD. 2018. Nature and mechanisms of aluminium toxicity, tolerance and amelioration in symbiotic legumes and rhizobia. Biol Fert Soils 54: 309-318. DOI: 10.1007/s00374-018$1262-0$.

Kaya Y, Akcura M, Taner S. 2006. GGE-Biplot Analysis of multienvironment yield trials in bread wheat. Turk J Agric For 30: 325 337.

Khoiriyah A, Putra ETS, Yudono P. 2016. Proline activity and growth of oil palm affected by aluminium toxicity and silica as ameliorant. Agric Sci 1 (1): 07-12. DOI: 10.22146/ipas.10786.

Klee HJ, Tieman DM. 2013. Genetic challenges of flavor improvement in tomato. Trends in Genet 29 (4): 257-267. DOI: 10.1016/j.tig.2012.12.003.

Ma B, Gao L, Zhang H, Cui J, Shen Z. 2012. Aluminum-induced oxidative stress and changes in antioxidant defenses in the roots of rice varieties differing in $\mathrm{Al}$ tolerance. Plant Cell Rep 31: 687-696. DOI: $10.1007 / \mathrm{s} 00299-011-1187-7$

Malecka A, Piechalak A, Zielinska B, Kutrowska A, Tomaszewska B. 2014. Response of the pea roots defense systems to the two element combinations of metals $(\mathrm{Cu}, \mathrm{Zn}, \mathrm{Cd}, \mathrm{Pb})$. Acta Biochimica Polonica 61 (91): 23-28

Marcon E, Hérault B. 2015. Entropart; an R package to measure and partition diversity. J Stat Softw 67: 1-26. DOI: 10.18637/jss.v067.i08

Navascués J, Pérez-Rontomé C, Sánchez DH, Staudinger C, Wienkoop S, Rellán-Álvarez R, Becana M. 2012. Oxidative stress is a consequence, not a cause, of aluminum toxicity in the forage legume Lotus corniculatus. New Phytol 193: 625-636. DOI: 10.1111/j.14698137.2011.03978.x.

Noctor G, Mhamdi A, Chaouch S, Han Y, Neukermans J, Marquez-Garcia B, Queval G, Foyer CH. 2012. Glutathione in plants; an integrated overview. Plant Cell Environ 35: 454-484. DOI: 10.1111/j.1365 3040.2011.02400.x.

Nurmalasari AI, Putra ETS, Yudono P. 2016. Root morphology of eight hybrid oil palms under iron $(\mathrm{Fe})$ toxicity. Agric Sci 1 (1): 13-18 10.22146/ipas.11254

Ratnasari S, Putra ETS, Indradewa D. 2017. Analysis of the growth of oil palm (Elaeis guineensis Jacq.) exposed by aluminum toxicity and silica as an amelioration. Agric Sci 2 (1): 15-19.

Ribero C, Cambraia J, Peixoto PNP, Junior EMF. 2012. Antioxidant system response induced by aluminum in two rice cultivars. Braz J Plant Physiol 24 (2): 107-116. DOI: $10.1590 / \mathrm{S} 1677$ 04202012000200004 .

Saravanan T, Bhaskaran R, Muthusamy M. 2004. Pseudomonas fluorescens induced enzymological changes in banana roots $(\mathrm{Cv}$
Rasthali) against fusarium wilt disease. Plant Pathol J 3 (2): 72-80. DOI: $10.3923 /$ ppj.2004.72.80.

SAS Institute. 2013. SAS System for Windows 9.4. SAS Institute, Inc., North Carolina, USA.

Shahnawaz MD, Sanadhya D. 2017. Aluminium induced oxidative stress and antioxidants system in two barley varieties and its alleviation through ascorbic acid and salicylic acid seed priming approach. Intl J Life Sci Pharm Res 7 (3): 26-37.

Sharma P, Dubey RS. 2007. Involvement of oxidative stress and role of antioxidative defense system in growing rice seedlings exposed to toxic concentrations of aluminum. Plant Cell Rep 26: 2027-2038. DOI: $10.1007 / \mathrm{s} 00299-007-0416-6$.

Shetty R, Sukumaran C, Vidya N, Prakash NB, Lux A, Vaculik M. 2021. Aluminum toxicity in plants and its possible mitigation in acid soils by biochar; a review. Sci Tot Environ 765: 645-653. DOI: 10.1016/j.scitotenv.2020.142744

Smith JL, Halvorson JJ, Papendick RI. 1993. Using multiple variable indicator kriging for evaluating soil quality. Soil Sci Soc Am J 57: 743-749. DOI:10.2136/sssaj1993.03615995005700030020x

Statistics Indonesia. 2019. Indonesian Oil Palm Statistics 2019. Statistics Indonesia, Jakarta, [Indonesian]

Sulaeman, Suprapto, Eviati. 2005. Analisis Kimia Tanah, Tanaman, Air, dan Pupuk. Balai Penelitian Tanah, Bogor. [Indonesian]

Suryanto P, Faridah E, Triyogo A, Kastono D, Suwignyo B, Nurmalasari AI, Alam T. 2020. Designing of soil quality and climate assessment tool for sustainable production of signal grass (Brachiaria brizantha) silvopasture system in mountain ecosystems. Aust J Crop Sci 14: 614621. DOI:10.21475/ajcs.20.14.04.p2147.

Utami T, Putra ETS, Tohari. 2019. Root morphology and growth response of oil palm (Elaeis guineensis Jacq) hybrid to $\mathrm{Al}$ toxicity at nursery. Agric Sci 4 (3): 140-145.

Valentovic P, Luxova M, Kolarovic L, Gasparikova O. 2006. Effect of osmotic stress on compatible solutes content, membrane stability and water relations in two maize cultivars. Plant Soil Environ 52 (4): 186191. DOI: $10.17221 / 3364-$ PSE.

Wei T. 2013. Corrplot: Visualization of a correlation matrix. R Package Version 073.

Welham SJ, Gezan SA, Clark SJ, Mead A. 2015. Statistical Methods in Biology; Design and Analysis of Experiments and Regression. CEC Press, Boca Raton, US.

Yan W, Hunt LA, Sheng Q, Szlavnics Z. 2000. Cultivar evaluation and mega environment investigation based on GGE-Biplot. Crop Sci 40 (3): 507-605. DOI: $10.2135 /$ cropsci2000.403597x

Yan W, Racjan I. 2002. Biplot analysis of test site and trait relations of soybean in Ontario. Crop Sci 42: 11-20. DOI: $10.2135 /$ cropsci2002.1100.

Yan W. 2001. GGE-Biplot a windows application for graphical analysis of multi-environment trial data and other types of two-way data. Agron J 93 (5): 1111-1118. DOI: 10.2134/agronj2001.9351111x. 